\title{
The Provision of Free Higher Education in South Africa: A Proper Concept or a Parable?
}

\author{
Halalisani Victor Mlambo*, Mduduzi Hlongwa, Mandla Mubecua \\ University of Zululand, KwaZulu-Natal, South Africa \\ *halavico@yahoo.com
}

\begin{abstract}
The provision of free-higher education is one of the most debated issues in South Africa today. The issue of free-higher education has drawn many commentators from sectors such as the media, business and within the political dominions. The main argument is where will the money to fund free-higher education will come from, whether the provision of free-higher education in South Africa is a proper concept or just a parable and also the terms of reference with regards to the provision of free-higher education in the country. By strictly examining the available and relevant literature on the concept of free-higher education in South Africa, the study was able to comprehensively understand the dynamics, implications and probability of providing free-higher education. Infrastructure challenges and economic growth are undoubtedly the major factors hindering the country from providing free-higher education, and unfortunately, with the government already forging ahead with implementing free-higher education without a proper and extensive feasibility study, the hasty implementation of free-higher education will have devastating implications for growth and service delivery in the country.
\end{abstract}

Keywords: Higher Education, Debate, Socio-Economic, Parable, Feasibility

\section{Introduction}

The 2016 widespread student protests advocating for the provision of free higher education across the country and the current state of restlessness in institutions of higher education led former President Jacob Zuma to establish a commission in January 2016, chaired by Justice Jonathan Arthur Heher (Ndaliso, 2017). The mandate of the Commission was to investigate, make findings, report on and make recommendations on the feasibility of making higher education free in South Africa, with regards to the Constitution of the Republic of South Africa, all relevant higher and basic education legislation, all findings and recommendations of the various presidential and ministerial task teams as well as all relevant educational policies, reports and guidelines; the multiple facets of financial sustainability, analysing and assessing the role of government together with its agencies, students, institutions, business sector and employers in funding higher education and training; and the institutional independence and autonomy which should occur like the financial funding model (The Presidency, 2017).Access to quality education is a pillar of strength in a country that is undergoing a developmental juncture, especially on socio-economic and political domains (Gunay \& Kazazoglu, 2016). An unaffordable and expensive provision of either basic or higher education can weaken the character and the appearance of a democratic country like South Africa in terms of producing a competent human capital ready to contribute to socio-economic development. South Africa has provided free-basic education since 2006 and it has been anticipated that eventually, higher education at some point will also be catered for. Free-higher education currently, is one of the most debated issues in the country (Bitzer, 2009). At the same time, previously disadvantaged students have continuously pushed for free-higher education, to show their determination and will, students took to the streets to voice out and register their anger and frustration at the slow pace at which free higher education was being prioritised (Fourie, 2018).

The issue of free-higher education has raised eyebrows in different sectors throughout media houses, business sector and in the political dominions. While these sectors have welcomed the idea of providing freehigher education, the main argument has been where will the money to fund free higher education will come from and whether the provision of free higher education in South Africa is a proper implementable and sustainable concept or a parable. It remains to be envisaged as to what direction that the country will take in terms of implementing the concept. Nonetheless, then president of the country, Mr Jacob Zuma, announced the implementation of free higher education in December 2017, (Mailovich, 2018). However, South Africa faces numerous challenges such as youth unemployment, unemployed graduates, poverty and a significantly low Gross Domestic Product owing to various economic constraints which have plagued South Africa. Furthermore, the number of universities in the country is miniature as the country only has twenty-six (26) universities. Moreover, universities can only accommodate a certain number of students, therefore, with the 
provision of free higher education in motion, it remains to be seen how universities will respond to this. Undoubtedly, the provision of free higher education has inspired great public debate and further engagement between the government, the management of universities and society at large. Notably, the student's dissatisfaction withstands despite the fact that South Africa's post-apartheid government discourse on statesociety relations is centred on greater inclusive education for the nation (Engelbrecht, 2006). This inclusive education is therefore reflected in the South African Constitution's commitment to everyone's right to further education, in which the state through reasonable measures must make higher education to be progressively available and accessible. Since the announcement of free higher education in December, numerous political and economic analysts have questioned the exact motive and economic feasibility of the plan. Without leaning towards a particular view, the study explores whether the provision of free-higher education in South Africa is a proper concept or a parable? The paper initiates by unpacking the concept free education in the context of South Africa. The concept of free higher education in South Africa is generally new and it has raised questions regarding its affordability. South Africa's economic growth is currently very low, tax collection is decreasing and unemployment is increasing, this, therefore, raises a question, can South Africa offer let alone afford free higher education? Therefore, the rational of the study is to carefully scrutinise the concept of free higher education in South Africa and most importantly understand if the country can afford it without major implications in the near future. South Africa's quest to implement free education must ensure that it does not hinder the provision of other essential public services in the country, hence the affordability factor will be very crucial going forward.

\section{Literature Review}

Operational Definition of Concepts: It is important for an author to define concepts when undertaking a study or when writing an academic paper. This is because a word can have two or more meanings. Defining concepts helps in a case where a reader perceives a word as meaning something else while in that particular study/paper it means something different. This makes it easier to make its context understandable in terms of the study at hand. Understanding a word differently can impact the content of a study acutely, which may have some repercussions into understanding it. Some concepts are defined below for the purpose of this study.

The term 'Free': According to Merriam Webber Dictionary (2016), "free means not costing or charging anything". This means that whatever the item or service that is said to be free is of zero cost, and it charges nothing.

Education: Oxford Dictionary (2015) states that "education is a process of receiving or giving a systematic instruction especially at school or university, or it is an enlightening experience". Supposedly, this means that there is an expert and a learner who acquires knowledge for future usage. During this process, an improved knowledge and developed skills are attained.

Free education: When considering the above, it can be said that free education is education that is incorporated with no costs to individuals acquiring it. The costs may be consumed by either public sector (business) or public sector (the government).

Understanding the concept free education in the context of South Africa: Universities South Africa (USAF) opined that "South Africa will still have a fee-based tertiary education system after government implements its new funding scheme". Because of this proposition, a pilot project had to be started which will entail funding only the entry-level students at higher institutions of learning (News24, 2018). This has to be extended to the following level per year for the period of five (5) years whereby it would reach the highest level of higher education. According to Bawa, the CEO of USAF, "each university will still set its own fee structure, to be approved by the institution's council, which will then be paid by bursaries funded by the Department of Higher Education" (News24, 2018). It can be said that it is free-higher education for all, but in actual fact, it is not because a huge number of potential students get left outside the boundaries of accessing higher education. While some are lucky acquire government's financial assistance, even after they do so, they are often shunned away at universities because of quotas set by universities. On a positive note, some 
learners acquire spaces to study but not financial assistance which then takes us back to ask the terms of reference for this free-higher education system being currently paraded in South Africa

Theorizing the concept of Free-Higher Education: According to Brenner et al. (2010), the failure of the Keynesian system in 1929-1930 resulted in a Great Depression, as a result, the Neoliberal economic system emerged in the development agenda. The policies of neo-liberalism promoted deregulation, privatization and the reduction of taxes (Palley, 2005). Under neoliberal policies, multilateral organisations (United Nations) participated in developmental activities. The Universal Declaration of Human Rights in 1948 proposed that education has to be free, especially at the elementary and fundamental stage (Bray and Kwo, 2013). In 1966, the International Covenant on Economic, Social and Cultural Rights declared that higher education shall be made equally accessible to all, on the basis of capacity, by every appropriate means, and in particular by the progressive introduction of free education. This partly displays the normal expansion of higher education, and consequently of the burden on governments (Bray \& Kwo, 2013). In 1990, there was the launch of the Education for All (EFA) movement at the World Conference on Education for All (WCEFA). In the event, there were 155 countries 33 international organisations and 125 nongovernmental organisations and institutes. The Summit recognised that higher education has to be paid. The concept free-higher education was rejected because nothing can be provided for free. Moreover, it did not promote the idea that school had to be free of charge (Bray \& Kwo, 2013). The targets of the EFA were connected to the United Nation's eight Millennium Development Goals (MDGs), both the EFA and the MDGs were prepared on the same era under the auspices of neo-liberalism. The implementation of free-higher education is expected to be funded by the general taxpayers, which include the parents of students and learners (Psacharopoulos \& Papakonstantinou, 2005). For that reason, the disapproval of the free-higher education under the neo-liberal policies cast serious doubts about the success of implementing and the sustainability of the free-higher education in South Africa. Moreover, the concept of free-higher education can be understood in the conceptual framework below.

\section{Figure 1: Conceptualization for Free-Higher Education}

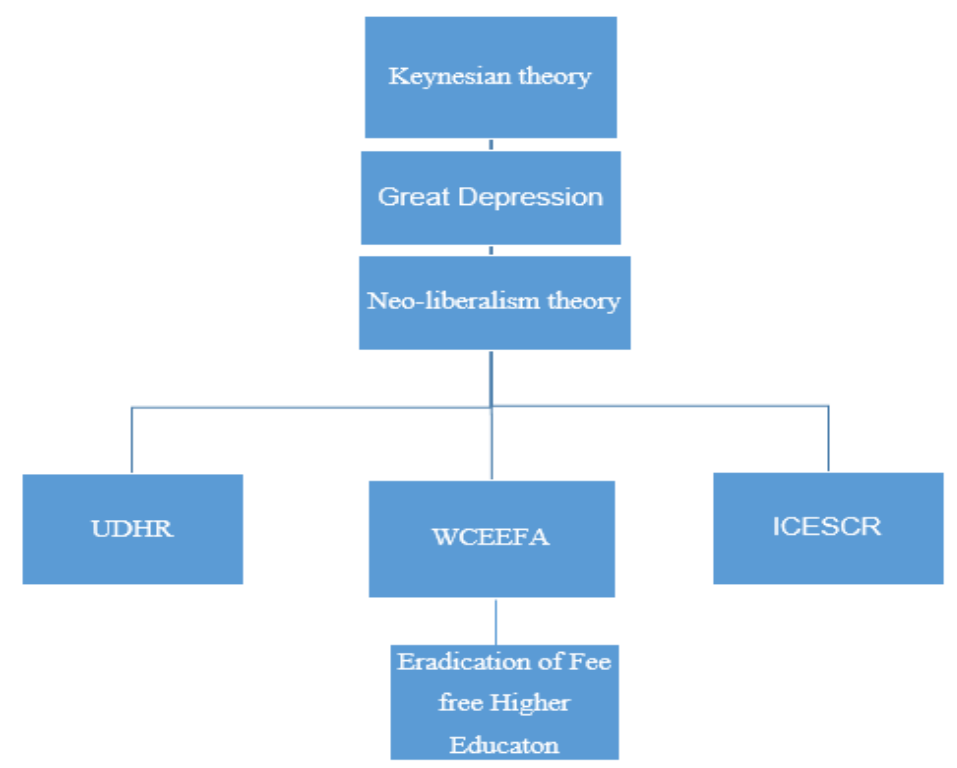

Source: Authors

Having theorised the concept free-higher education above, the paper provides a framework (Figure 1) that helps to understand how the neo-liberal policies cancelled the very idea of free-higher education. It has been stated above that neo-liberalism emerged following the failure of the Keynesian system, which resulted in the Great Depression. The neo-liberalism through International Covenant on Economic, Social and Cultural Rights in 1966, declared the provision of free-higher education. However, in 1990, the UN held a conference (World 
Conference on Education for All) which suggested that higher education should not be provided for free (Banerjee \& Sharma, 2007). The dissatisfaction of providing free-higher education gives guidelines that it won't be easy for the country to successfully implement it. Although free-higher education may start well in South Africa, it may, however, have a negative effect in the long run economically. Regardless of the disapproval of the concept under neo-liberalism policies, the country (South Africa) is currently experiencing numerous challenges which may affect the current and the long-term sustainability of free-higher education. Some of these challenges are discussed below.

Crisis and free-education in South Africa: The Freedom Charter (1955) specifies that "The Doors of Learning and Culture Shall be Opened! It emphasizes that "education shall be free, compulsory, universal and equal for all children; Higher education and technical training shall be opened to all by means of state allowances and scholarships awarded on the basis of merit (The Freedom Charter, 1955). It puts an emphasis that "education shall be free, compulsory, universal and equal for all children; Higher education and technical training shall be opened to all by means of state allowances and scholarships awarded on the basis of merit (The Freedom Charter, 1955). Parker (2014) stipulates that "free" and "compulsory" refer squarely to basic education. Higher education and technical training, must "be opened to all" - that is, made accessible though financial support". This undertaking may have a different view of what most citizens consider the true definition of what the Freedom Charter articulates. This has become the foundation for the free education in the country's basic education levels and has enforced the current juncture whereby the free higher education demand escalated excessively and uncontrollably in almost all institutions of higher education (Gumede, 2018). This emancipated late in 2015 where students registered their anger over the slow pace in the delivery of free-higher education.

The notion of free-higher education gained prominent momentum after university students from all corners of South Africa protested in 2016 which led to numerous buildings been destroyed and vandalised in most universities across the country (Business Tech, 2016). This shook the whole country in a way that even opposition parties in parliament swerved from their main agenda of the time which was \#ZumaMustFall and turned their focal point to \#Free Education. Protesters were further motivated by the arrest of some student leaders (Mcebo Dlamini from Wits University \& Bongumusa Khanyile from Durban University of Technology). Debatably one may opine that today, newly recruited students (first years) are enjoying the benefits of the scars and pains felt by those who partook in those strikes. This is because the government seems to have taken the wants of students and seemingly responded to them positively. Numerous authors, economists, analysts and journalists have been wavered and irresolute about the funds for free-higher education. This compelled the president to establish the commission to investigate whether free-higher education is implementable and economically doable in the country, hence this gave birth to the Heher Commission. The then President of the country, Mr Jacob Zuma, announced in December's ANC national conference that there will be free-higher education to all first-year students from 2018 and this will go on-and-on for a period of five years (Mailovich, 2018). This means that by the year 2022, there will be free-higher education to all university levels from entry level to the highest level. Even after that announcement, there were still uncertainties pertaining to where the money to fund free higher education will come from.

The political circles in South Africa have swirled with the term free higher education, with many political figures especially in the African National Congress (ANC), opining that it is the key in ensuring the development of previously disadvantaged groups (Muller, 2018). However, many political and economic analysts have questioned the true motives and economic feasibility of the plan with some dismissing it as a political tool being used to draw young and disgruntled university students who have been failed by the South African higher education funding mechanism (Masuku, 2017). The concept according to politicians would allow disadvantaged groups to equally compete with previously advantaged groups in gaining access to tertiary education. The question then is, who will fund the model, what are the economic implications and will it really be a success. Glenn and Castle (2018) uphold that "someone has to pay for education because it is physically impossible to deliver quality education while charging students nothing. If it is not students taking care of their responsibilities, it is the taxpayers who will pay through substantial grants and scholarships awarded to students every year". The issue of free higher education aims to resemble other free services provided by the government to the society at large. These services include low-cost housing, health services e.g., services provided in clinics and hospitals, free primary and secondary education and the provision of law 
enforcement agencies (Ayeni, 2001). Glenn and Castle (2018) further state that "it is wrong to place this burden on the general population for a decision entirely resting on the individual's shoulders. Making education free would mean the money has to be found from elsewhere. The only options available to the government would be to raise taxes or cut services elsewhere. This can be seen in the next coming years whereby the South African government may introduce a special tax collection strategy in order to fund higher education. If the government considers reducing the budget allocation from other services in order to cater for free higher education, it will have negative repercussions for service delivery. Glenn et al. (2018) mention that it is not sufficient to reduce funding for other vital services than it is to make students pay for education. It does not solve the problem; it only shifts the problem onto another part of the population. This is another prolific prospect of overlooking the whole concept of the free-higher education in the country. Furthermore, the country's nominal GDP and the whole economy of the country does not give the benefit of the doubt in being compelled to cater and fully subsidise higher education for all.

Funding free-higher education: where will the money come from? When looking at the might-be sources of funds to finance free higher education, Glenn et al. (2018) articulate that "increasing taxes to pay for education will reduce personal freedoms. Economic freedom directly correlates with personal freedoms and by cutting disposable income through the raising of tax; it reduces the options available for families across the country. The household's income will be lessened which will refrain each family from advancing in its predilections. Some would argue that making education free would open up colleges and universities to a greater number of students, however, according to Glenn et al. (2018), this would not be the case. Although higher education is not free, it is in no way meant to exclude certain people from accessing it. Furthermore, a vast majority of students receive student loans to pay for tuition and maintenance, thus implying that there are no barriers for students to consider higher education even without a free tuition system. Such narratives are debatable because not all previously disadvantaged students are eligible or qualify for loans even those such as the National Student Financial Aid Scheme (NSFAS) which are government funded. With the current student loan system, lenders are far more forgiving and the repayments are much lower than a conventional loan. According to Glenn et al. (2018), the system already allows students to climb up the career ladder before they start to pay back significant amounts. They further opine that reducing fees would also make it more difficult to continue to improve the standard of education within schools and colleges. If these institutions cannot generate income from charging their students, they can only make enough to cover their operational costs and cannot invest in themselves and boost standards. This would only lead to the continuing decline of the country's higher education facilities and make the country less attractive for international students.

Areas of concern: South Africa only has 26 universities which is a huge challenge for the intake of all matriculates who exit secondary education each year. According to TVET Colleges South Africa (2018), "there are fifty (50) registered and accredited public TVET colleges in South Africa which operate more than 264 campuses spread across the rural and urban areas of the country. These public TVET Colleges are established and operated under the authority of the Continuing Education and Training Act 16 of 2006 and fall under the Department of Higher Education and Training. When considering the number of TVET colleges (50) comparing it to the number of 2017 matriculates (full-time and part-time) which was 798289 (Gerber, 2017), one can tell that there are limited spaces to accommodate all those in need of higher education. TVET Colleges South Africa (2018) further opine that public TVET Colleges are subsidised by the state with approximately R8 billion per year. There are considerably more than 700000 students in public TVET Colleges. The 2019/2020 target is that there should be 1238000 students in TVET Colleges. This means that TVET Colleges are in a rapid growth and development phase. This advances to the fact that the government has to invest more money towards TVET colleges in order to align with more intakes in the upcoming years. According to Helen Suzman Foundation (2013), "education in all its forms and at all levels needs to display the following interconnected and essential features: availability, accessibility, acceptability and adaptability i.e.:

- Availability - functioning educational institution must be available to all learners. This entails the provision of buildings, sanitation facilities for both sexes, teaching material, libraries, computer facilities and access to the internet.

- Accessibility - has three overlapping dimensions: non-discrimination, physical accessibility and economic accessibility; meaning education must be affordable, within safe physical reach, and must be granted on a non-discriminative basis. 
- Acceptability - the form and substance of education, including curricula and teaching methods, have to be acceptable. This refers to the relevance, appropriateness and quality of education, subject to educational objectives required.

- Adaptability - education has to be flexible so it can adapt to societal changes and respond to the needs of learners within their diverse social and cultural settings".

The above-mentioned features of education point in one direction, the government is expected to expedite and avail education so that anyone who wishes to accesses higher education experiences no barriers. Another area of concern is that the country's 2017 GDP growth projection, which has been revised upward to 1 percent, which is higher than the 0.7 percent expected at the time of Medium Term Budget Policy Statement (MTBPS) last year. The country is anticipating growth of 1.5 percent in 2018, rising to 2.1 percent in 2020 (South Africa Budget Speech: 2018). Furthermore, the Minister of Finance stated that while this is a good start, there are immediate policy interventions that we need to make to ensure that we create the right environment for investment, growth and employment (South Africa Budget Speech, 2018). This plays a crucial role in service provision and job creation in the country. It cannot be denied that a country's growth is determined through the availability of infrastructure development, education and health facilities and technological advancements etc. A country's education system is one of the most fundamental and critical fragment that makes a strong country and it always requires special attention.

Legislative and other mandates: The Department of Higher Education and Training Annual Report (2016/2017) stated that the constitutional mandates the Department of Higher Education and Training descends its legislative mandate from the supreme law of the Republic of South Africa, the Constitution, within the relevance of Section 29, read with Schedule 4, which lists education at all levels, excluding tertiary education as a functional area of concurrent national and provincial legislative competence, whereas Section 29 states as follows: firstly, everyone has the right (a) to a basic education, including adult basic education; and (b) to further education, which the state, through reasonable measures, must make progressively available and accessible". It further says that, secondly, everyone has the right to receive education in the official language or languages of their choice in public educational institutions where that education is reasonably practicable. In order to ensure the effective access to and implementation of this right, the State must consider all reasonable educational alternatives, including single medium institutions, taking into account (a) equity; (b) practicability; and (c) the need to redress the results of past racially discriminatory laws and practices". Thirdly, "everyone has the right to establish and maintain, at their own expense, independent educational institutions that (a) do not discriminate on the basis of race; (b) are registered with the state, and (c) maintain standards that are not inferior to standards at comparable public educational institutions. It also says that "Fourthly, Sub-section 3, does not preclude state subsidies for independent educational institutions", (Department of Higher Education and Training Annual Report, 2016/2017). These give a clear insight as to what/how education in all levels should be structured in both public or private educational systems, and the exclusion of tertiary education has already tarnished the appraisals given to the national legislature. Salim Vally in Education Policy Consortium Paper 5 (2015) pointed out, that "approach to education, despite lip service to empowering poor communities is embedded in the neo-liberal obsession with technocratically-driven and fiscally conservative governance. This has not only impacted on the quantifiable aspects of education but also on its content and quality".

\section{Methodology}

The concept of free higher education is new in South Africa, it is a new and buzzing concept that has been widely discussed and debated in society, more especially concerning its affordability, and therefore, the study used the available secondary data in order to contextualize the concept of free higher education in South Africa. This method was helpful in looking at the concept from a policy point of view and in its holistic perspective, as a result, to deeply understand this new concept in a South Africa context. The study relied on extensively secondary sources as a means of collecting relevant and required data. It employed strict textual analysis of the available literature relevant the concept of free-higher education in South Africa. The qualitative research approach was utilized in the course of this study. The purpose of this approach was to put into context the understanding the underlying concept of free-higher education in South Africa and whether this approach is economically viable and more importantly will it be sustainable should it be 
implemented and to also thoroughly engage existing literature to understand and dissect the socio-economic impact of free-higher education in South Africa. Forrester (2010) asserts that qualitative research uses methods such as participant observation or case studies which result in a narrative descriptive account of a setting or practice. While relevantly new, various scholars have tried to understand the concept of free-higher education, therefore there are rich sources of information, though some of these sources may not comprehensively speak directly to the provision of free-higher education in South Africa, they nonetheless offer views on the subject matter which will be utilized to further enrich the study.

\section{Findings and Discussion}

The concept of free-higher education has and is currently being debated in many political and economic circles in South Africa. The country's government has however forged ahead with its plans of introducing free-higher education, but the question of funding, implementation and sustainability remain unanswered. Whether the government will be able to sustain the concept remain to be seen, but undoubtedly, the concept has raised more questions than answers.

Economy and sustainability: Booysen (2016) stated that as governments across the African continent experience fiscal constraints owing to uncertainty in the global financial markets and weak local economies, funding for higher education is becoming more constrained. The current total regional expenditure in this area as percent gross to GDP is 0.78 percent, way below that of Organization for Economic Cooperation and Development (OECD) member countries, which is more than 1.5 percent of GDP in at least seventeen countries. This begs to question whether South Africa's free provision of higher education will be fruitful or not and whether funding will be available in the long term. Booysen (2016) then stated that the South African government's contribution to higher education funding in the democratic era has been on the steady increase, R11 billion in 2006 to R26 billion in 2013. In his 2017/2018 Budget Speech, then Minister of Finance, Mr Malusi Gigaba announced a staggering R57 billion for the realization of free-higher education and furthermore this massive amount only covers first-year students for now (Mokone, 2018). This sum is expected to increase next year as second-year students will be covered too. This will happen for the next five years. Contrary to the worries of analysts and journalists, then Minister of Higher Education and Training, Ms Hlengiwe Mkhize enunciated that funding for higher education will be available for the upcoming five years and the government does not know what will happen thereafter (ANN7, 2018). Debatably one may assume, judging from the minister's statement that government has not done a feasibility study to assess the longterm sustainability with regards to providing free-higher education.

The Provision of free-higher education can be viewed as positive and welcomed initiative because not only does it encourage young South Africans to enroll for higher education, but it also allows for millions of previously disadvantaged groups to access higher education. However, the major concern for analysts and policymakers is that with South Africa currently experiencing sluggish rates of economic growth, high unemployment, rampant corruption and mal-administration, the question then is where will the funds required to fund free-higher education come from and how will this affect economic growth. The country has been averaging 1.2 to 2 percent growth annually since the end of the 2008 financial crisis and with the cost to fund the initial phase of free-higher education reported to be around R60 billion, clearly South Africa in its current economic uncertainty cannot afford such a steep figure. One solution is for government to curb spending and reduce funds to other departments in order to raise the needed capital to fund free higher education (Donnelly, Patel, \& Letsoalo, 2017), but analysts say this will further add strain to the economy as the country has already seen a R50bn in tax shortfall, sluggish economic growth and a high unemployment, reducing funds to other departments will ultimately affect public service delivery in the country. Some argue that government should increase its partnership with private organizations to fund higher education rather than government going at it alone as it will be a huge cost to the economy. The OECD (2012), also states that rather the government should provide free-higher education at different levels rather than to provide freehigher education in its totality. The Higher Commission, which was set up by former president Jacob Zuma explicitly stated that South Africa cannot afford free higher education currently, the commission opined that South Africa's economic condition makes it impossible for the government to provide free education. The commission suggested that training and vocational colleges should provide free registration but those who could afford to pay must pay. The commission noted that the country currently does not have the money to 
implement free education and forcefully implementing the concept of free education would undoubtedly result in other important services being less prioritized. In 2016, then finance minister Pravin Gordan stated that South Africa cannot afford free education, he cited weak economic growth as the major reason. The former minister stated that if the country does not grow economically, it cannot create extra revenue needed to realize the provision of free higher education, however, he stated that more must be done by the government to ensure that the poor and vulnerable have access to higher education. Furthermore, former statistician-general Pali Lehohla opined that lazy students are to blame for holding back the implementation of free higher education, Lehohla stated that lazy students take time to finish their qualifications and end up using extra financial resources which could have been allocated to other potential students.

Quality of education: Pink and Noblit (2017) opine that anything that is free is usually associated with poor quality and unfortunately, the higher education system needs investments for it to run optimally and be innovative and attractive, therefore the idea of free-higher education in South Africa will likely reduce the quality of education offered. Chou (2014) furthermore; alludes that education especially higher education is an ever-changing phenomenon, and needs steady financial inflow in order for it to grow and develop. On the other hand, Robbins (2001) states that South Africa cannot sustain free higher education currently as the economy of the country does not support the idea, while the author acknowledges that it would be a great achievement for the country as it would allow South Africans from all corners to access higher education, however, the country's economic outline is not really in support of the idea and hence forcibly implementing free higher education for political benefits will exert tremendous pressure on the country's finances as the funds needed to realize free-higher education will be hard to come by. Timeslive (2017) conclude by mentioning that while free-higher education is positive step in terms of human capital development, developing regions face serious economic structural challenges which end up affecting growth and therefore South Africa must be vigilant in ensuring that implementing the concept of free-higher education does not affect the output in terms of quality at higher learning institutions. Snodgrass (2016) argues that South Africa must ensure that the provision of free higher education does not compromise the provision of quality education. Aall \& Crocker (2017) state that in Africa, the implementation of universal free primary and secondary education greatly undermined the quality of education offered in schools. In the case of Uganda, through surveys, it was found that leaners in schools that were offering free education could not read or solve arithmetic problems. Snodgrass (2016) further argues that while education should be accessible to everyone, universities in South Africa ought to be innovative and develop solutions to complex issues in society, all this must take place in a conducive environment characterized by continuous investments. This has led experts to warn that the continuous pressure for South Africa to provide free education may eventually lead to the reduction in the quality of education offered at South African universities. Universities need adequate investments to function optimally, and furthermore, the government cannot guarantee sufficient and consistent investments for South African universities, hence the continuous call for free education must be carefully implemented based on available resources.

Pressure on universities: With free-higher education been chanted across South Africa, this will surely put severe pressure on universities to admit more qualifying students, exceeding the recommended studentlecturer ratio, thus resulting in potential overcrowding. Universities have previously stressed that they have not been adequately consulted on how the concept of the free-higher education would be done in terms of its implementation, already this year many universities have encountered registration troubles as many students demanded to register for free. The concept of free-higher education is still in its early stages of implementation, hence a lot of uncertainty still exists, undoubtedly though; universities will be under severe pressure to make for an increased number of students, thus, forcing universities to invest in infrastructure development. The University of South Africa (Unisa), stated the provision of free education in South Africa without a proper feasibility and financing plan will put universities under tremendous pressure to enroll more students. The university stated that already many South African universities are functioning at the edge of their capacity, and therefore cannot expand without consistent capital investments. Furthermore, Ligami (2017) states that universities are always under pressure to be innovative and hence need sustained investments to ensure innovation is possible, however, the announcement of free higher education without proper research into its affordability and implications will further pressurize South African universities. With South African universities already functioning under a tight budget and with limited investments in infrastructure, the premature announcement of free higher education may further exacerbate the crisis. Many 
universities are overcrowded and lecturer halls accommodate an exceeded number of students, hence the announcement of free education will undoubtedly exert tremendous pressure on universities going forward.

\section{Conclusion and Suggestions}

Undisputedly, the question of free higher education remains and will remain a burning issue in South Africa's political and economic society. With the government already implementing the concept, many wonder whether it will be effective and sustainable, considering that South Africa is currently experiencing an economic growth problem. Furthermore; the funds to fund free-higher education will be highly problematic. The reduction in budget allocation to other departments in order to fund free-higher education will be negative for service delivery, this, therefore, entails that government must be very observant when implementing the concept of free-higher education so that it does not affect the functioning of other departments and the country's economic growth. It is with this pretext that the study recommends:

Increase Private-Public partnerships: Undeniably the private sector plays a huge role in South Africa and benefits from graduates produced by the country's universities. Therefore, a long-term and sustainable plan would be for the government to increase its collaboration with the private sector in terms of funding higher education. Both parties need to develop a mutually benefiting plan that will contribute towards the funding of higher education. Therefore, the government must not embark on funding higher education individually as this will be rather cumbersome and it will further put a strain on government resources. Former higher education minister Blade Nzimande stated that government cannot fund free higher education alone, and urged the private sector to be involved. The bill for funding free higher education is likely to grow significantly as more and more students aim to enroll for higher education, and with the government already operating under a tight budget, accommodating an increase in the number of students will prove to be very difficult. Therefore, the private with its financial capability may play a huge role in aiding government to provide free education. The private sector may undertake this function by this by providing grants, bursaries and scholarships to students. However, it is worth to note that the private sector in South Africa is already providing these, and therefore this implies that they would have to significantly increase these in order to accommodate a growing number of students

Reduce government spending: Undoubtedly, to fully implement free higher education in this current economic climate, the government would need to reduce funding on other public services in order to divert funds towards free higher education. Regrettably, though, this will result in other developmental projects being greatly affected in the process. Because the current economic climate does not allow South Africa to provide free education, reducing financial allocation to other services/departments may be the only way to fund free higher education without increasing taxes, however, it is also worth to note that this will have devastating implications for socio-economic development and public service delivery in South Africa.

Invest in the construction of new Infrastructure: The government should have anticipated that while universities have quotas in terms of the number of students they going to admit yearly, the concept of freehigher education has undoubtedly put them into a tight corner, and with insufficient facilities like lecture halls, student residences to accommodate an increased number of students, the government should prioritize the funding, development and the building of new universities in order to accommodate an extra load of students that will surely seek higher education buoyed by the term free-higher education. Moreover, there are limited universities in South Africa, it is also stated above that even the enrollment spaces in universities are limited, with this, clearly it means the country needs more universities in order for the program to be effective, sustainable and accommodate an increasing number of students. Many universities in South Africa are already struggling to secure adequate investments in infrastructure development, many universities are battling to fund student residences as more and more and students are enrolling for higher education, therefore; this calls for an increase in infrastructure investments. Surely, the implementation of free higher education will result in an increase in those hoping to enroll for higher education, so the provision of quality infrastructure will ensure that the implementation of free education adequately supported by infrastructure availability. 
Invest in TVET colleges: The thinking in many young South Africans is that universities are better than TVET colleges and offer better employment opportunities, however in reality colleges are vital for the South Africa's economy as they produce graduates who have a combination of theoretical and practical information, people who are ready to enter the workplace unlike university graduates who have a mostly theoretical understanding. Consequently, the government must market TVET colleges and invest in their development and ensure that they attract students just like universities. Scarce skills, which are careers such are artisans, riggers and boilermakers are available in TVET colleges, and these are careers which South Africa is in dire need of, this meaning government must ensure the colleges are effective and efficient.

Increase government subsidies/grants to universities: Government subsidies to universities play a huge role in the overall running and functioning of universities, the provision of free higher education has exerted tremendous pressure on universities to prioritize the fundraising initiatives in order to cater for the increasing operational costs. Therefore, increasing the subsidies to universities will ensure that financially, they are able to use these subsidies to cater for the increasing operational costs, however, these subsidies have to be consistent as operating costs are forever increasing.

Increase management oversight at universities: Over the past 10 years, many South African universities, especially those in rural areas have been characterized by financial uncertainty because of the mismanagement of finances. Therefore, if the government is pushing ahead with implementing free higher education, it must also ensure that universities have sufficient systems in place that will monitor financial transactions as to avoid corruption and maladministration. Some South African universities have been previously blamed for having to squander millions of rands and to a great extent. If corruption is prevalent in universities, free higher education will be impossible to implement, hence the continuous advocating for proper accountability systems to ensure transparency. The concept of free-higher education in itself is a great idea as it will allow many previously disadvantaged students to access quality education, however, the funding for the concept and its implementation is a worrying factor especially because the economic growth is currently sluggish and while government has already gone ahead with its implementation, the sustainability factor will undeniably remain. It also suggests a provocative thought on whether the concept will be successful in its implementation and sustenance or rather it is used as political tool to garner votes.

\section{References}

Aall, P. \& Crocker, C. (2017). The Fabric of Peace in Africa: Looking Beyond the State. McGill-Queen's PressMQUP. Quebec

ANN7. (2018). Vuka Afrika. Halfway House. South Africa.

Ayeni, V. (2001). Empowering the Customer (No. 13). Commonwealth Secretariat. Westminster. United Kingdom

Banerjee, A. \& Sharma, M. (2007). Reinventing the United Nations. PHI Learning. New Delhi.

Bitzer, E. (2009). Higher Education in South Africa: A scholarly look behind the scenes. African sun media. Stellenbosch

Booysen, S. (2016). Fees Must Fall: Student Revolt, Decolonisation and Governance in South Africa. South Africa: Wits University Press.

Bray, M. \& Kwo, O. (2013). Behind the façade of fee-free education: Shadow education and its implications for social justice. Oxford Review of Education, 39(4), 480-497.

Brenner, N., Peck, J. \& Theodore, N. (2010). After neo-liberalization? Globalizations, 7(3), 327-345.

BusinessTech. (2016). Damage to SA universities hits R600 million - and counting. Retrieved from: https://businesstech.co.za

Chou, P. (2014). The SSCI Syndrome in Higher Education: A Local or Global Phenomenon. Rotterdam: Sense Publishers.

Donnelly, L., Patel, K.\& Letsoalo, M. (2017). How you will pay for Zuma's free education plan, viewed 11 February 2018 from https://mg.co.za.

Education Policy Consortium (EPC) Paper 5. (2015). Education and the Freedom Charter: A Critical Appraisal. South Africa: Workers' World Media Production.

Engelbrecht, P. (2006). The implementation of inclusive education in South Africa after ten years of democracy. European journal of psychology of education, 21(3), 253. 
Forrester, M. (2010). Doing qualitative research in psychology: A practical guide. California. Sage.

Fourie, J. (2018). The hidden cost of free higher education. Retrieved from: https://www.fin24.com

Gerber, J. (2017). Fewer learners to write matric in 2017, viewed 20 February 2018 from https://www.news24.com/

Glenn, L. \& Castle, M. (2018). Argumentative Essay: Free Education. Scholar Advisor, viewed 14 February 2018 from: https://www.scholaradvisor.com.

Gumede, A. (2018). Zuma's free university promise may cause registration chaos. Retrieved from: https://www.timeslive.co.za

Gunay, E. \& Kazazoglu, G. (2016). National Innovation Efficiency During the Global Crisis: A Cross-Country Analysis. Springer. Berlin

Helen Suzman Foundation. (2013). The Right to Basic Education., viewed 20 February 2018 from http://hsf.org.za/

Ligami, C. (2017). Universities under pressure to focus on quality. Retrieved from: http://www.universityworldnews.com

Mailovich, C. (2018). Where is Zuma getting the money for free higher education from, asks SACP. Retrieved from: https://www.businesslive.co.za

Masuku, S. (2017). Free higher education in South Africa: Cutting through the lies and statistics. Retrieved from: https://www.iol.co.za/

Mokone, T. (2018). R57-billion for free tertiary education, viewed 13 February 2018 from https://www.timeslive.co.za

Muller, S. (2018). Free higher education in South Africa: Cutting through the lies and statistics. Retrieved from: https://mg.co.za

Ndaliso, C. (2017). Heher Commission: 'The elite will have universities to themselves'. Retrieved from: https://www.iol.co.za.

News24 (2018). SA will have a fee-based, not 'free' education in 2018 - Universities SA, viewed on 12 February 2018, from: https://www.news24.com

Organisation for Economic Co-operation and Development. (2008). Reviews of National Policies for Education Reviews of National Policies for South Africa. OECD Publishing. Paris

Parker D. (2014). University Education in the Department of Higher Education and Training, viewed on 12 February 2018 from: https://www.dhet.gov.za

Pink, W. \& Noblit, G. (2017). Second International Handbook of Urban Education. Berlin: Springer.

Psacharopoulos, G. \& Papakonstantinou, G. (2005). The real university cost in a "free" higher education country. Economics of Education Review, 24(1), 103-108.

Robbins, S. (2001). Organisational behaviour: global and Southern African perspectives. South Africa: Pearson.

Snodgrass, L. (2016). Free education comes at the cost of equality. Fin24. Retrieved from: https://www.fin24.com/

South Africa Budget Speech. (2018). South Africa Budget Speech. National Treasury. Cape Town.

The Department of Higher Education and Training Annual Report. (2016/2017). viewed on 20 February 2018, from: http://www.dhet.gov.za

The Freedom Charter. (1955). Adopted at the Congress of the People, Kliptown, South Africa.

The Organization for Economic Co-operation and Development. (2012). Higher Education in Regional and City Development Higher Education in the free state, South Africa 2012. Paris: OECD.

The Presidency. (2017). Release of the Report of Commission of Inquiry into the Feasibility of making High Education and Training Fee-free in South Africa. Retrieved from: http://www.thepresidency.gov.za

Timeslive. (2017). Free higher education for all poor students within five years, says Zuma. Available from: https://www.timeslive.co.za. [Accessed on 12 February 2018].

TVET Colleges South Africa. (2018). http://www.tvetcolleges.co.za/Site_Public_FET.aspx 